\title{
Infographic: fifteen years of Brazilian Journal of Motor Behavior
}

\author{
FABIO A. BARBIERI ${ }^{1}$ | JOSÉ A. BARELA² | NATÁLIA M. RINALDI ${ }^{3}$ \\ ${ }_{1}$ São Paulo State University (Unesp), School of Sciences, Department of Physical Education, Human Movement Research Laboratory (MOVI-LAB), Bauru, Brazil. \\ 2 São Paulo State University (Unesp), Rio Claro, SP, Brazil. \\ ${ }^{3}$ Center of Physical Education and Sports, Department of Sports, Federal University of Espirito Santo, Brazil.
}

Correspondence to: Fabio Augusto Barbieri. Av. Eng. Luiz Edmundo Carrijo Coube, 14-01, Vargem Limpa.Bauru, SP CEP 17033-360. Phone + $55143103-9612$. email: fabio.barbieri@unesp.br

https://doi.org/10.20338/bjmb.v15i5.276

ABBREVIATIONS
BJMB

BJMB Brazilian Journal of Motor Behavior

SOCIBRACOM Brazilian Society of Motor Behavior

PUBLICATION DATA

Received 05102021

Accepted 07112021

Published 01122021
Access infographic in https://socibracom.com/bjmb/index.php/bjmb/article/view/276/306.

KEYWORDS: Motor behavior | Motor control | Motor learning | Motor development

\section{INTRODUCTION}

The Brazilian Journal of Motor Behavior (BJMB) is a quadriannual, peer-reviewed, free of charge/fee and open-access journal published by the Brazilian Society of Motor Behavior (SOCIBRACOM). The BJMB has published original contributions within the multidisciplinary study of human motor behavior, in the broad scope of motor control, development and learning, movement disorders, sports, clinical, theoretical and model studies. Since 2019 the BJMB publishes manuscripts only in English. In the same year, BJMB started to invite researchers to be guest editors in article collections, providing an excellent opportunity to promote high-quality contents within the field.

The BJMB is the main motor behavior journal in the Latin American. It is widely recognized for its significant academic contribution and indexed in the UlrichsWeb Global Serial Directory, Diadorium, Gale Directory Library, Google Scholar, Road Directory of Open Access Scholary resources and Red Iberoamericana de Innovación y Conocimiento Científico. The number of edition and papers has sustainable and significantly increased in the last years, with over 500 authors contributing with 121 manuscripts, distributed in 40 numbers. The time of peer-reviewed process is short (first revision- 26 days) and paper publication is quick ( 57 days).

The BJMB was launched with its first edition published in December of 2006 and, thus, we are celebrating its 15th anniversary. For that, the BJMB launches a new type of manuscript: INFOGRAPHIC. This initiative aims to provide a quick, easy-to-use and enjoyable publication that conveys notable knowledge. Two types of infographics will be publishable: a) theory perspective: visual material to theory acknowledge to facilitate the understanding of models, theory frameworks, concepts, principles, and approaches in the field; b) article infographic: visual material about interventional effects on motor learning, development and control sustained by reviews and/or meta-analysis. 
The infographic section will be added to those already existing: research, systematic review and meta-analysis, mini review, scoping review, research notes, current opinion, critique, and tutorials. It is interesting to highlight the section about tutorial, which emphasizes and provides reflection on the use of one or several methods or selfinstruction in motor behavior. Finally, the current opinion section publishes pieces of diverse authors around the world that provide perspectives on a hot, relevant, and perhaps controversial topic within the scope of BJMB.

We would like to congratulate all for this important occasion and to wish that the BJMB continues publishing impactful and relevant contributions in the motor behavior field still for many years to come.

Citation: Barbieri FA, Barela JA, Rinaldi NM. (2021). Infographic: Fifteen years of Brazilian Journal of Motor Behavior. Brazilian Journal of Motor Behavior, 15(5):287-288.

Editors: Dr Fabio Augusto Barbieri - São Paulo State University (UNESP), Bauru, SP, Brazil; Dr José Angelo Barela São Paulo State University (UNESP), Rio Claro, SP, Brazil; Dr Natalia Madalena Rinaldi - Federal University of Espírito Santo (UFES), Vitória, ES, Brazil.

Copyright:@ 2021 Barbieri, Barela and Rinaldi and BJMB. This is an open-access article distributed under the terms of the Creative Commons Attribution-Non Commercial-No Derivatives 4.0 International License which permits unrestricted use, distribution, and reproduction in any medium, provided the original author and source are credited. Funding: This research did not receive any specific grant from funding agencies in the public, commercial, or not-forprofit sectors.

Competing interests: The authors have declared that no competing interests exist.

DOI: https://doi.org/10.20338/bjmb.v15i5.276 